\title{
DDC wt Allele
}

National Cancer Institute

\section{Source}

National Cancer Institute. DDC wt Allele. NCI Thesaurus. Code C128875.

Human DDC wild-type allele is located in the vicinity of 7p12.2 and is approximately 107 $\mathrm{kb}$ in length. This allele, which encodes aromatic-L-amino-acid decarboxylase protein, is involved in monoamine neurotransmitter synthesis. Mutation of the gene is associated with aromatic L-amino-acid decarboxylase deficiency (AADCD). 